\title{
ARM Based Smart Water Meter with LoRa for Soilless Agriculture Application
}

\author{
Caner Baydur ${ }^{1}$, Savaş Şahin $^{2}$, Alkım Gökçen $^{3}$, Bahadır Yeşi1 ${ }^{4}$ \\ ${ }^{1}$ İzmir Kâtip Celebi University, Faculty of Engineering and Architecture, Departmant of Electrical and Electronics Engineering, Izmir, Türkiye, (ORCID: 0000-0003- \\ 2605-5635), canerbaydurr@gmail.com \\ 2 İzmir Kâtip Celebi University, Faculty of Engineering and Architecture, Departmant of Electrical and Electronics Engineering, Izmir, Türkiye, (ORCID: 0000-0003- \\ 2065-6907), sahin.savas@yahoo.com \\ ${ }^{3}$ Baylan Ölçü Aletleri Sanayi ve Ticaret LTD. ŞTİ. Department of Research and Development, Izmir, Turkey, (ORCID: 0000-0002-8131-388X), \\ alkim.gokcen@outlook.com \\ ${ }^{4}$ Baylan Ölçü Aletleri Sanayi ve Ticaret LTD. ŞTİ. Department of Research and Development, Izmir, Turkey, (ORCID: 0000-0002-9622-2593), \\ b.yesil@baylanwatermeters.com
}

(3rd International Congress on Human-Computer Interaction, Optimization and Robotic Applications June 11-13, 2021)

(DOI: $10.31590 /$ ejosat.957639)

ATIF/REFERENCE: Baydur, C., Şahin, S., Gökçen, A. \& Yeşil, B. (2021). ARM Based Smart Water Meter with LoRa for Soilless Agriculture Application. European Journal of Science and Technology, (26), 352-357.

\begin{abstract}
The aim of this study is to develop an integrated and micro-controller based electronic circuit which might be used in soilless agriculture and smart greenhouse systems. In this study, a novel soilless agriculture system design is proposed to measure and monitor parameters such as the desired ambient temperature, nutrient solution temperature, solution alkalinity $(\mathrm{pH})$ and conductivity in the greenhouse. In addition to the design, a control mechanism is designed to keep the amount of nutrient solution, which changes over time, stable in the desired ranges. This proposed system consists of two different embedded systems where the necessary parameters are measured, actuators are controlled, and the related input / output pairs are observed. The yield of the nutrient solution in the system is continuously controlled, and the necessary conditions are provided for the growth of the product in the greenhouse. The microcontroller system is responsible for data transmission in the greenhouse, observing the pipes, and to identify possible problems which might be encountered in the corresponding lines. In addition, the embedded system in the field performs the control tasks of the actuators which takes a role in maintaining the temperature inside the greenhouse taking into account the feedback data. LoRa communication is employed to construct a data flow network between embedded systems. For this purpose, a new communication protocol is proposed to be used in soilless agriculture applications. In order to enable the users to observe the whole system in multi-greenhouse systems, a control unit (computer) is positioned over a main greenhouse where the relevant inputs / outputs of the embedded system can be read. The sensor and actuator data are obtained during the studies, the necessary conditions for soilless agriculture are examined, and the results are presented.
\end{abstract}

Keywords: STM32 Microprocessor, Soilless Agriculture, LoRa Communication, Smart Meter

\section{Topraksız Tarım Uygulaması için LoRa ile ARM Tabanlı Akıllı Su Sayacı}

$\ddot{\mathbf{O} z}$

Bu çalışmanın amacı topraksız tarım yetiştiriciliğinde, akıllı sera sistemlerinde kullanılabilecek, kablosuz haberleşme modülüne entegre ve mikro-denetleyici tabanlı elektronik kart geliştirmektir. Bu çalışmada, serada istenen ortam sıcaklığı, besin çözelti sıcaklığı, çözelti alkalinitesi $(\mathrm{pH})$ ve iletkenlik gibi parametreleri ölçmek ve izlemek için yeni bir topraksız tarım sistemi tasarımı kullanılmıştır.

\footnotetext{
${ }_{1}^{1}$ Corresponding Author: İzmir Kâtip Çelebi Üniversitesi, Mühendislik ve Mimarlık Fakültesi, Elektrik-Elektronik Mühendisliği Bölümü, İzmir, Türkiye, ORCID: 0000-0003-2605-5635, canerbaydurr@gmail.com
} 
Tasarımın yanı sıra, zamanla değişen besin çözeltisi miktarını tekrar istenen seviyeye getirmek için bir kontrol mekanizması tasarlanmıştır. $\mathrm{Bu}$ sistem, parametre ölçümlerinin alındığı, gerekli eyleyicilerin kontrol edildiği ve ilgili giriş/çıkış çiftlerinin gözlemlendiği iki farklı gömülü sistemden oluşmaktadır. Sistemdeki besin solüsyonun verimi sürekli kontrol edilerek serada ürünün büyümesi için gerekli koşullar sağlanacaktır. Serada veri aktarımından sorumlu mikrodenetleyici sistemi de boruları gözlemlemek ve ilgili hatlarda karşılaşılabilecek olası sorunları tespit etmekle de görevlendirilmiştir. Ayrıca sahada bulunan gömülü sistem, sera içi sıcaklığın korunmasında rol oynayacak olan havalandırma sistemi ve sıcak hava pompası gibi eyleyicilerin kontrolünü gerçekleştirebilir. LoRa iletişimi, gömülü sistem arasında bir veri akışı ağı oluşturmak için kullanılır. Bu amaçla topraksız tarım uygulamalarında kullanılmak üzere yeni bir iletişim protokolü oluşturulmuştur. Kullanıcıların çoklu sera sistemlerde tüm sistemi gözlemleyebilmesi için, gömülü sistemin ilgili giriş / çıkışlarının okunabileceğ bir ana sera üzerine bir kontrol ünitesi (bilgisayar) konumlandırılmıştır. Çalışmalar sırasında elde edilen algılayıcı ve eyleyici verileri toplanmış, topraksız tarım için gerekli şartlar incelenmiş ve sonuçlar sunulmuştur.

Anahtar Kelimeler: STM32 Mikroişlemci, Topraksız Tarım, LoRa Haberleşme, Akıllı Sayaç

\section{Introduction}

Agriculture has an important place in the country's economy as it supplies raw materials to the industrial sector, contributes to exports, contributes to national income, contributes to the nutrition of the population and employment (Uzundumlu, A. 2012). Due to the increasing environmental pollution and soilrelated problems, soilless agriculture vegetable cultivation in the greenhouse has begun to increase as a solution to traditional soilbased agriculture systems in the world and in our country (Aydoğan \& Gül, 1999; Tüzel et al., 2007). Soilless agriculture is becoming widespread today and the follow-up of the nutrient solution required for plant nutrients is an important process and there are varieties such as hydroponic, aquaponic and aeroponic (El-Kazzaz, K.A. and El-Kazzaz, A.A. 2017). It has gained an important value in many countries thanks to keeping the quality of the plant under control, allowing production in areas where the soil is not suitable and keeping the water use under control (Özgümüş \& Kaplan, 1992; Sevgican, 2003; Gül, 2008).

Rate of IoT-based automation system employments are increasing in traditional agricultural practices significantly, offer solutions to problems encountered in agriculture and related fields (Ananthi, N., Divya, J., Divya, M., \& Janani, V. 2017, April). Efficiency can be increased by adding lighting into the system (Kodali, R. K., Jain, V., \& Karagwal, S. 2016, December). In addition, gases in the greenhouse can be monitored using atmospheric sensors (Shirsath, D. O., Kamble, P., Mane, R., Kolap, A., \& More, R. S. 2017). The GSM communication system, automated plant irrigation and monitoring system are the examples of technologies used in the agricultural applications (Priya, C. G., Pandu, M. A., \& Chandra, B. 2017, April). Fuzzy logic-based control systems are also examples used for greenhouse (Azaza, M., Tanougast, C., Fabrizio, E., \& Mami, A. 2016). In order to find solutions to the problems encountered in traditional agriculture and soilless agriculture, solutions have been sought using today's technological infrastructure and there are new solutions to make the systems more convenient.

In this study, there are 2 modules, one of which is inside the greenhouse. The module inside the greenhouse transmits values such as $\mathrm{pH}$, conductivity, ambient temperature, and nutrient solution temperature to the meters in the tank system where the nutrient solution is located and allows the values to be monitored. In addition, it enables new nutrient solution to be added to the system when the specified interval in the nutrient solution is exceeded. An interface over MATLAB has been designed to monitor data in the system. Since energy is important for the module used in the field, the module goes into sleep mode to consume low power after the required values are sent. For the module in the field, when the temperature values decrease, the pump that delivers hot air can be operated to increase the temperature thanks to the relays, or the ventilation system can be opened to reduce the temperature when the temperature increases. The graph of the change of nutrient solution values was obtained as a result of the experiment. By using LoRa technology in soilless agriculture applications, the greenhouse system becomes more intelligent. A more economical solution is brought to the costly applications used in soilless agriculture applications and offers a more flexible system of availability. In addition, data will increase with the increase in the number of greenhouses or the number of modules. A new protocol is designed to ensure communication between greenhouses and the total capacity of the modules is 64 bytes.

The rest of the paper is organized as follows: In Section 2, the sensor, actuator, relay, motor, ARM based micro-controller and LoRa module used in the system are mentioned. In Section 3, results are given. Conclusions and recommendations of the study are indicated in Section 4.

\section{Material and Method}

The overall system consists of greenhouse temperature sensor, nutrient solution temperature sensor, $\mathrm{pH}$ sensor, conductivity sensor, 2 relays for ventilation and temperature pump, STM32L4 microprocessor and LoRa modules which construct the communication background. The proposed system is established in order to monitor and control the nutrient solution in the system by establishing a smart control system in soilless agriculture.

\subsection{Peripheral Units}

Temperature sensor has an internal structure similar to the working principle of the thermistor. With the change of temperature, the resistance also changes. The temperature calculated in Kelvin is used by converting to degrees Celsius. There is a $4.7 \mathrm{k}$ resistor on the circuit and the resistance falling on the sensor can be calculated with the voltage divider. Its measurement range is $-55^{\circ} \mathrm{C} \sim 315^{\circ} \mathrm{C}$. Supports $3 \sim 5 \mathrm{~V}$ wide voltage input.

The temperature sensor is used to measure the properties of conductor and semiconductor resistance parameters such as temperature change, thermal resistance, temperature. It can measure precisely at high temperatures. The measurement range is $-50^{\circ} \mathrm{C} \sim 250^{\circ} \mathrm{C}$, and sensor supports $3 \sim 5 \mathrm{~V}$ wide voltage supply. It is widely used in industrial applications. It has been used in the measurement of nutrient solution due to its waterproof 
feature. The conductivity sensor can be used to measure the electrical conductivity of the aqueous solution and assess water quality, which is frequently used in aquaculture and environmental water sensing and/or related fields. The desired values are obtained by computing the voltage drop rates on voltage divider circuit.

It is important for the development of the plant that the product to be produced in soilless agriculture remains within the specified $\mathrm{pH}$ ranges (Domingues, D. S., Takahashi, H. W., Camara, C. A., \& Nixdorf, S. L. 2012). The pH sensor in Fig. 1 measures the hydrogen-ion concentration in the nutrient solution. This device determines whether the nutrient solution is acidic or basic. BNC connector, which constructs the physical connection between sensor and solution, is used as a measurement probe. Measurement $\mathrm{pH}$ range is $0 \sim 14$, and sensor supports $5 \mathrm{~V}$ voltage supply input. It has adjustable linear calibration gain potentiometer. Operating temperature range $0{ }^{\circ} \mathrm{C} \sim 60^{\circ} \mathrm{C}$ with a measurement sensitivity $0.1 \mathrm{pH}(25 \mathrm{C})$.

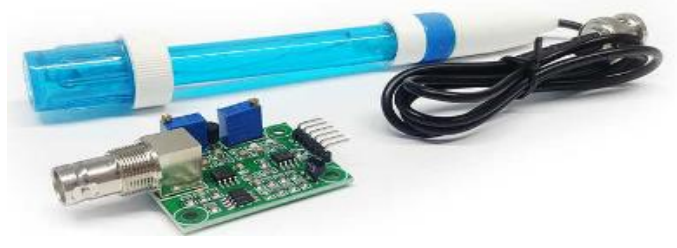

Fig. 1. Diymore Analog pH Sensor

Relay in Fig. 2 is employed to control motors by an on/off process. It has maximum switching voltage of $250 \mathrm{~V} \mathrm{AC}$ and rated carrying current up to $120 \mathrm{~A}$. The relay is turned on and off by turning the motor located inside. It maintains either contact position indefinitely without power applied to the motor. This motor rotation-based structure prevents the magnetic disturbance effects on switching process. Thus, a motor driver circuit is designed and employed to drive the relay motor.

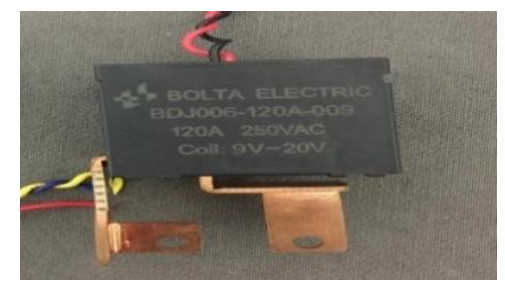

Fig. 2. Relay for Ventilation and Heating

The water and/or solution flow might be interrupted under necessary conditions by employing a valve. This valve operation voltage is 3 Volts with a working temperature range between -10 ${ }^{\circ} \mathrm{C} \sim 60^{\circ} \mathrm{C}$. Rotation direction might be determined according to the polarity of the supply voltage, and position of the shaft is determined by considering the states of the internal switches.

The solution supply is employed to control the nutrient solution $\mathrm{pH}$ and $\mathrm{EC}$ parameters which effects the feeding process.
If $2 \mathrm{ml}$ a solution and $2 \mathrm{ml}$ b solution are mixed in 1 liter of water, the EC value of the water increases by $2.2 \mathrm{mS} / \mathrm{cm}$. A solution has $10.3 \%$ total nitrogen $(\mathrm{N}), 1.6 \%$ ammonium nitrogen $(\mathrm{NH} 4), 8.7 \%$ nitrate nitrogen (NO3), 7.5\% water-soluble potassium oxide $(\mathrm{K} 2 \mathrm{O}), 8.6 \%$ calcium $(\mathrm{Ca}), 0.3 \%$ iron dtpa $(\mathrm{Fe})$. B solution has $2.1 \%$ total nitrogen $(\mathrm{N}), 2.1 \%$ nitrate nitrogen (NO3), $6.4 \%$ water soluble phosphorus pentaoxide (P2O5), $11.6 \%$ water soluble potassium oxide (K2O), 1\%, It contains 6 magnesium $(\mathrm{Mg}), 0.1 \%$ manganese $(\mathrm{Mn}), 0.1 \%$ zinc $(\mathrm{Zn}), 0.03 \%$ Boron (B), $0.003 \%$ copper $(\mathrm{Cu}), 0.004 \%$ molybdenum (Mo).

The STM32 L476RG Nucleo board in Fig. 3a provides an affordable and flexible way for users to create trials and prototypes by choosing from a variety of performance, power consumption and feature combinations. The SX1276MB1MAS in Fig. $3 \mathrm{~b}$ is employed together with the microcontroller board for communication process, and which has ISM frequency bands at $433 \mathrm{MHz}$ and $868 \mathrm{MHz}$ for use in China and Europe respectively. Thus, data monitoring process might be performed, and process control related parameter measurements might be transmitted to corresponding microcontroller units.

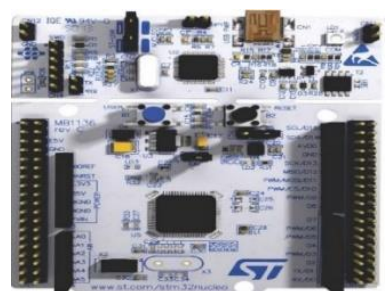

(a)

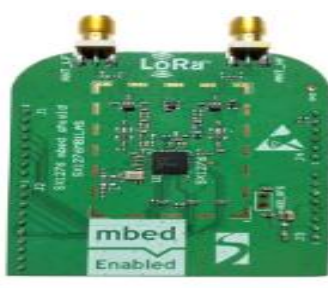

(b)
Fig. 3. Micro-controller and Communication Module (LoRa)

\subsection{Proposed Soilless Agriculture System}

Communication algorithm of LoRa modules is given in Fig. 4. Sensors are added to the system after they are first calibrated. The STM32L4 microcontroller wakes up and collects data from the sensors. It sends the data to the meters with the LoRa module. LoRa uses $868 \mathrm{MHz}$ frequency as required by European standards and uses the previously created protocol while broadcasting. Data is sent to the meters every hour and it is checked whether the data is within predetermined intervals. According to the results, the meters are opened or not. Finally, it is sent to the computer to track the data. 


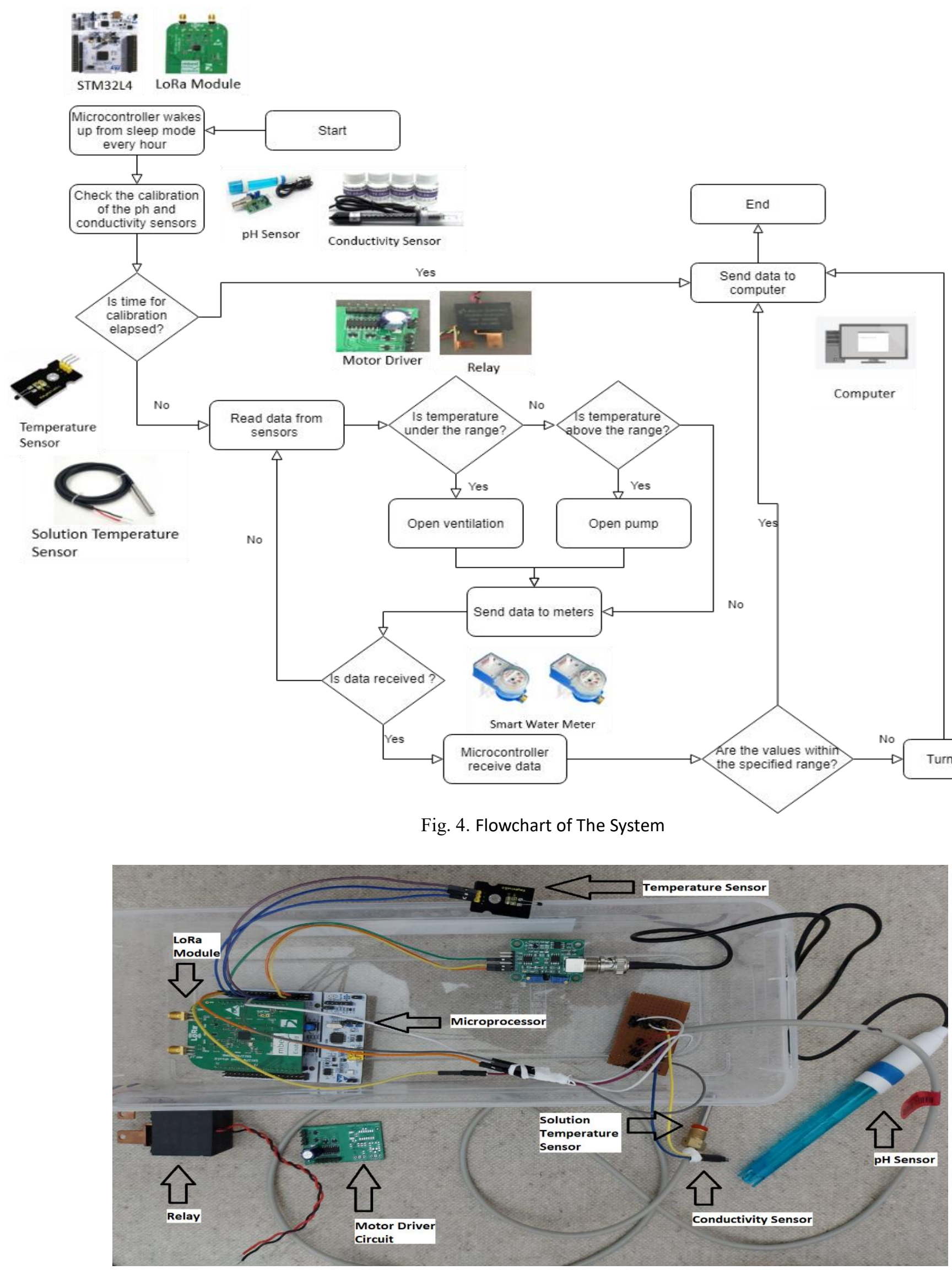

Fig. 5. System Overview 


\section{Results and Discussion}

Lettuce is chosen to grow in the proposed system, and it is purposed to keep the nutrient solution specific parameters in the desired range. The sampling period of the necessary parameters is one hour. The required $\mathrm{pH}$ range for lettuce is 6-7, and the EC range is $800-1200 \mathrm{uS} / \mathrm{cm}$. There are 4 sensors, which read sensor measurements, connected to the module in the greenhouse. These sensors send values such as $\mathrm{pH}$ of the nutrient solution, conductivity, nutrient solution temperature and greenhouse temperature to the microcontroller. The microcontroller controls the temperature parameters and there are 2 relays that operate the hot air pump and / or ventilation system when the temperature parameters exceed the specified ranges. The microcontroller transmits the data to the meters with the LoRa module. Data are checked in meters and valves are opened if $\mathrm{pH}$ and conductivity exceed specified values. The data are transmitted to the computer via UART for monitoring. It can be viewed through an interface made in the MATLAB application designer in Fig. 6a. In cases where the module in the greenhouse will work with battery, it switches to sleep mode after sending data every hour to save energy. Through its low power consumption, it can continue to send data for a long time. In addition, a novel protocol is designed to be used in soilless agriculture systems. As it might be seen in Fig. $6 \mathrm{~b}$ the change of $\mathrm{pH}$ and EC might be observed and parameters changes do not exceed the specified ranges, and the continuity of the desired nutrient solution is ensured. Also, lettuce rooting and growth, with the proposed system, in healthy way might be observed in the Fig. 7.

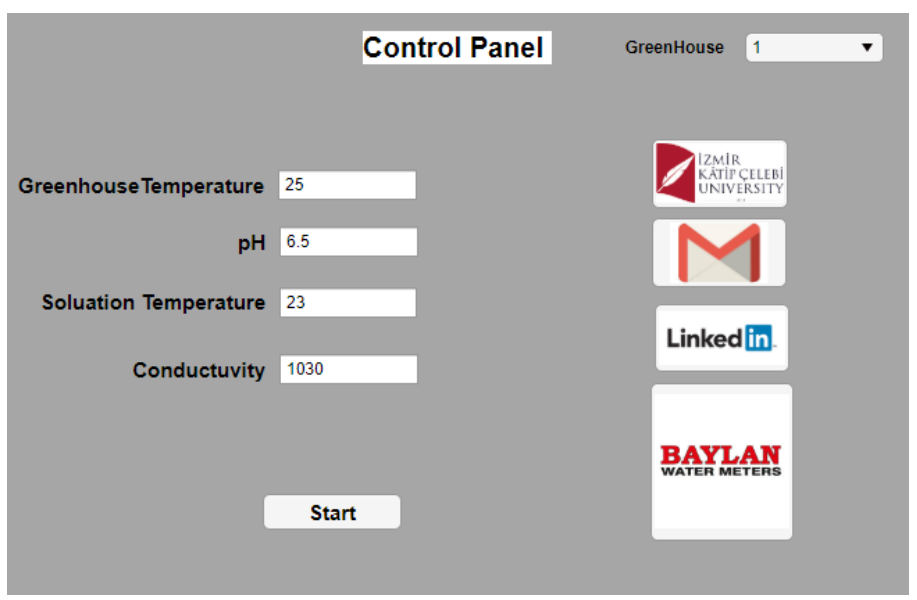

(a)
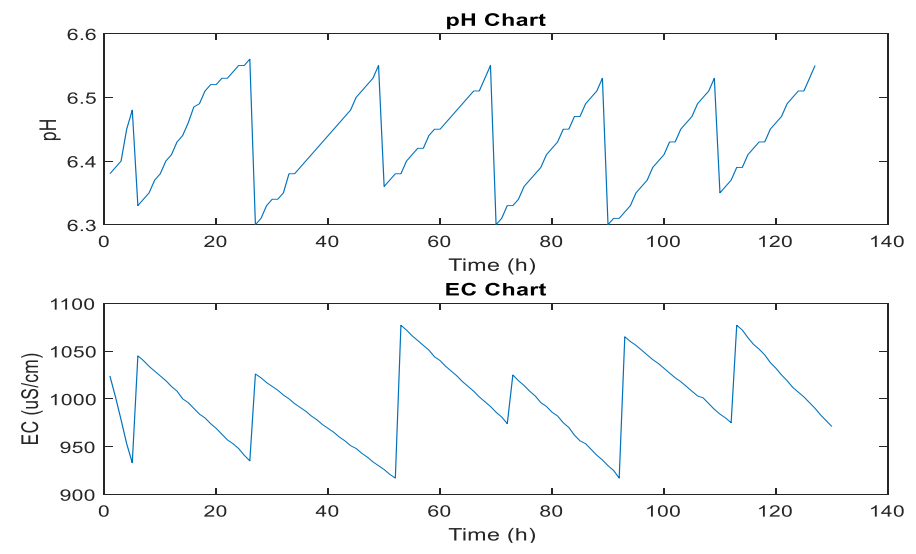

(b)

Fig.6. (a) Main Interface, and (b) Hourly Nutrient Solution Data
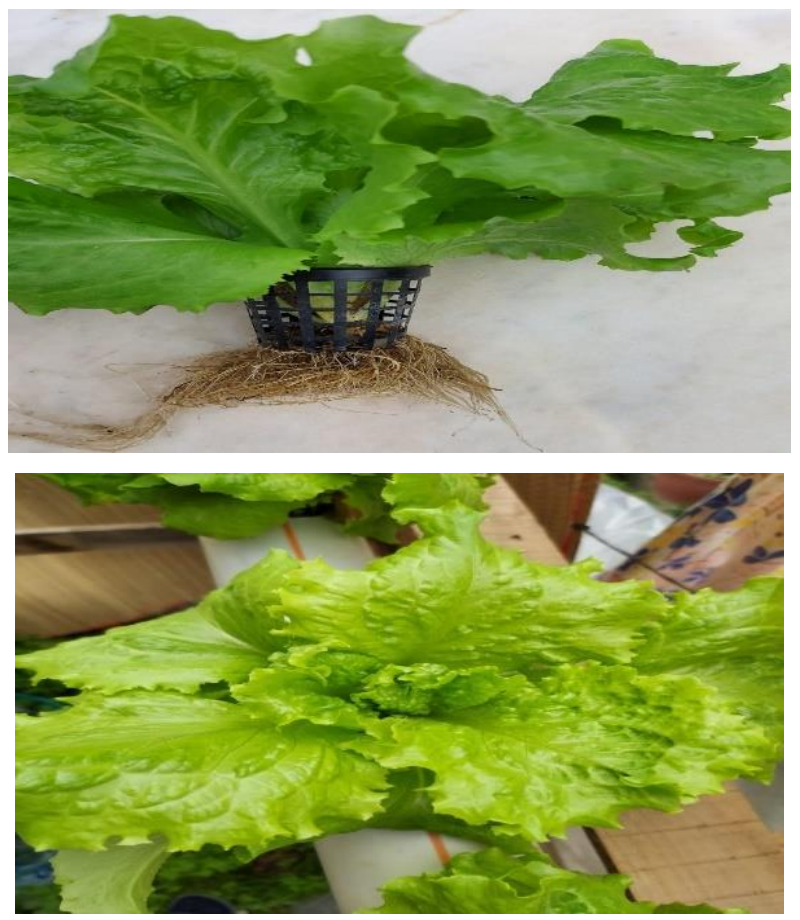

Fig.7. Greenhouse Grown Lettuce

\section{Conclusions and Recommendations}

In this study, an alternative design to the systems used in traditional greenhouse agriculture and soilless agriculture is employed and tested. For the plant grown in soilless agriculture, the nutrient solution should be controlled and monitored precisely. This requirement is provided with LoRa module which is connected to ARM-based microcontroller unit. The data received from the module in the field are transmitted to the meters and in this way, nutrient solution is to be controlled in the desired ranges. In addition, as understood from the results of the designed system, the communication protocol can be used successfully in these systems. The necessary parameter measurements obtained from the system is monitored on a main computer. The design specifications are explained, and both implementation conditions are indicated. A lettuce growing application is performed, details of the procedure are explained, and results are presented. Results indicates that proposed system showed a sufficient performance on both process control and communication tasks. Also, a lettuce is successfully grown in the research period. In the future directions, a machine learning based method might be employed to analyze and construct the relation between nutrient solution parameters and growth.

\section{Acknowledge}

This work is supported by the Scientific and Technical Research Council of Turkey (TUBITAK) under 2209B-Bachelor Final Thesis Focused on Industry Program with Project number 1139B412000905.

\section{References}

Ananthi, N., Divya, J., Divya, M., \& Janani, V. (2017, April). IoT based smart soil monitoring system for agricultural production. In 2017 IEEE Technological Innovations in ICT for Agriculture and Rural Development (TIAR) (pp. 209214). IEEE. 
Aydoğan, N.G., Gül, A., 1999. Topraksız kavun yetiştiriciliğinde torba özelliklerinin bitki gelişimi ve verime etkileri. Türkiye 3. Ulusal Bahçe Bitkileri Kongresi, 343-347.

Azaza, M., Tanougast, C., Fabrizio, E., \& Mami, A. (2016). Smart greenhouse fuzzy logic based control system enhanced with wireless data monitoring. ISA transactions, 61, 297-307.

Domingues, D. S., Takahashi, H. W., Camara, C. A., \& Nixdorf, S. L. (2012). Automated system developed to control $\mathrm{pH}$ and concentration of nutrient solution evaluated in hydroponic lettuce production. Computers and electronics in agriculture, 84, 53-61.

El-Kazzaz, K. A., \& El-Kazzaz, A. A. (2017). Soilless agriculture a new and advanced method for agriculture development: an introduction. Agri Res Tech, 3, 63-72.

Gül, A., 2008. Topraksız Tarım, Hasad Yayıncılık, 144s.

Kodali, R. K., Jain, V., \& Karagwal, S. (2016, December). IoT based smart greenhouse. In 2016 IEEE region 10 humanitarian technology conference (R10-HTC) (pp. 1-6). IEEE.

Priya, C. G., Pandu, M. A., \& Chandra, B. (2017, April). Automatic plant monitoring and controlling system over GSM using sensors. In 2017 IEEE Technological Innovations in ICT for Agriculture and Rural Development (TIAR) (pp. 173-176). IEEE.

Sevgican, A., 2003. Örtüaltı Sebzeciliği (Topraksız Tarım) Genişletilmiş 2. basım Cilt II, Ege Üniversitesi Ziraat Fakültesi Yayınları No: 526, Ege Üniversitesi. Basımevi, Bornova-İzmir.

Shirsath, D. O., Kamble, P., Mane, R., Kolap, A., \& More, R. S. (2017). IoT based smart greenhouse automation using Arduino. International Journal of Innovative Research in Computer Science \& Technology, 5(2), 234-238.

Uzundumlu, A. S. (2012). Tarım sektörünün ülke ekonomisindeki yeri ve önemi. Alınteri Zirai Bilimler Dergisi, 22(1), 34-44. 